\title{
Ђорђе Микић*
}

Оригинални научни рад

UDK 342.25 (497.6)

\section{ПИТАЊЕ АУТОНОМИЈЕ БОСНЕ И ХЕРЦЕГОВИНЕ КАО СРПСКА САМООДБРАНА}

The question of autonomy of Bosnia and Herzegovina as Serbian self-defence

\begin{abstract}
This work discusses the historical struggle of Serbian people in Bosnia and Herzegovina for the autonomous freedom, through numerous rebellions and uprisings in the $19^{\text {th }}$ century, such as rebellions and uprisings of Serbs in Šumadija. After its success in Serbia under the rule of Miloš Obrenović, Serbs'struggle for the autonomous freedom in Bosnia and Herzegovina in the last period of the Ottoman and later Austro-Hungarian authority was a "categorical imperative of Serbian selfdefence". Resistance to foreign occupiers in Bosnia and Herzegovina was repeated after the disintegration of Yugoslavia in 1991, with the struggle for the autonomous freedom in the Republic of Srpska, for its achievements, challenges and perspectives. On both of these occasions, Serbian people remained and fought for their freedom and unity in the community with other nations. On both of these occasions, destiny and outcome of this successful struggle with opponents were earlier in hands of great powers and later in hands of powerful states. Their earlier and later attitudes towards Serbs were different. Compared to Bulgarians and Bulgaria, or Cretans and Crete, after whose uprisings the great powers awarded them the autonomy, they only promised the same to Serbs while some of them opposed it and corrupted, up until the end of the First World War. It was similar with the struggle of Serbs in Bosnia and Herzegovina for freedom in the achieved Republic of Srpska, up until the United States of America took Bosnia and Herzegovina in its own hands. The States, in cooperation with the Contact Group members, ended the civil war in Bosnia and Herzegovina at the meeting in Dayton in the USA in 1995, while at the same time legitimising the Republic of Srpska within the two-entity Bosnia and Herzegovina.
\end{abstract}

Key words: Bosnia and Herzegovina, Muslims, Serbia, Serbs, Montenegro, Russia, Austria-Hungary, Turkey, Andrassy, Gorchakov, Ignatyev, Disraely, Derby, Porta, Constantinople, Berlin, Kallay, Nikola Stojanović.

Сажетак: У раду се разматра историјска борба српског народа у Босни и Хериеговини за аутономну слободу кроз многе буне и устанке у XIX веку,

\footnotetext{
Историчар, profesor emeritus Независног универзитета Бања Лука.
} 
Ђорђе Микић: Питање аутономије Б и Х као српска самоодбрана

попут буна и устанака Срба у Шумадији. После њеног успеха у Србији под Милошем Обреновићем, борба Срба за аутономну слободу у Босни и Херцеговини у заврином раздобљу турске и касније аустроугарске управе била је „категорички императив српске самоодбране“. Отпор страним окупаторима у Босни и Херцегговини репризиран је после растурања југословенске државе 1991. године, борбом за аутономну слободу у Републици Српској, за юена достигнућа, изазове и перспективе. Иу једном и у другом времену, српски народ је остајао и борио се за своју слободу и јединство у заједници са другим народима. И у једном и у другом времену судбина и исход те успешне борбе са противницима били су у рукама раније великих сила, а касније моћних држава. Њихово раније и касније понашање према Србима било је различито. У односу на Бугаре и Бугарску и Крит и Крићане,после чијих устанака су им силе дале аутономују, Србима су само обећавале и при томе једне се супростављале и квариле, све до краја Првог светског рата. Слично је било и са борбом Срба у Босни и Херцегговини за слободу у извојеваној Републици Српској, све док Сједињене Америчке Државе нису узеле Босну и Хериеговину у своје руке. Оне су, заједно са чланицама Контакт групе, окончале грађански рат у Босни и Херцеговини на састанку у Дејтону у САД 1995. и озакониле Републику Српску у двоентитетској Босни и Хериеговини.

Кључне речи: Босна и Хериееговина, Муслимани, Србија, Срби, Црна Гора, Русија, Аустроугарска, Турска, Андраши, Горчаков, Игњатијев, Дизраели, Дерби, Порта, Цариград, Берлин, Калај, Никола Стојановић.

Тражећи себи тему и реч у програму овог научног скупа, као историчар XIX века, настојао сам да изаберем оне који фигурирају као друштвена и историјска подлога на којој је израсла Република Српска са својом 20-годишњом историјом. С обзиром да се код нас историја борбе за слободу и државу понавља, борба за настанак Републике Српске, планови међународних представника, мапе поделе Босне и Херцеговине скоро у целини се репризирају протеклих сто и више година трајања борбе за аутономну слободу. Само замена личности, имена места одлучивања, бројни састанци, конференције, конгреси и разговори, показују да су борба Срба Босне и Херцеговине за аутономију у завршном раздобљу турске власти и борба Срба за Републику Српску стално били објекат великих сила и моћних држава. Тек у завршној фази аустроугарске управе у Босни и Херцеговини и на састанку у Дејтону Босна и Херцеговина је постала субјективни фактор преговарачких односа у борби за аутономну слободу, односно Републику Српску. Историја је показала, да иако је пројекат за аутономну слободу у Босни и Херцеговини текао 
истовремено и упоредо са покретима Бугара и Крићана, није имао истоветне резултате, па се у Босни и Херцеговини морао да понови у покрету за Републику Српску.

Научну обраду теме „Република Српска - 20 година развоја достигнућа, изазова и перспективе“ историја може само да подупире и објашњава. Само је историјска прича „залог сигурне будућности“. Са политичким и државноправним питањем настанка и двадесетогодишњице развоја Републике Српске најуже је повезано питање борбе за аутономију у бившим окупационим системима и међународном окружењу.

Наслов овог саопштења узет је као парафраза наслова једног текста борца и писца аутономне борбе Босне и Херцеговине у аустроугарском раздобљу, др Николе Стојановића: „Захтев потпуне аутономије наша је самоодбрана, категорички императив нашег самопоуздања“".

Пут аутономне борбе у Босни као и у Србији кренуо је почеткомXIX века. Иако је у Босанском пашалуку било више српског народа него у Београдском, у њему, захваљујући томе што је везир Бећир-пашасломио отпор незадовољника, у Босни није дошло до револуције ни појаве аутономног покрета. ${ }^{2}$ У односу на Србију, она је дуго била чврста, јединствена, компактна административна јединица у Османском царству, са јаком средњовековном традицијом.Као таква, није успела да се избори, макар као Војводство Србија и Тамишки Банат, за језгро будуће државне заједнице у виду аутономног статуса. ${ }^{3}$ То није успело ни првим поборницима покрета за аутономију Босне и Херцеговине међу Муслиманима - Хусеин-капетану Гардашчевићу 1830-их година, а међу Србима - херцеговачком устанику Луки Вукаловићу 50-их и 60-их година, као ни устаницима у Херцеговини и Крајини у устанку 1875-78.

Питање аутономије Босне и Херцеговине крајем 60-их и почетком 70-их година XIX века, у раздобљу великог устанка 1875-78. до Берлинског конгреса и аустроугарске окупације 1878. уско је везано с интересом и политиком великих сила, са Србијом и Црном Гором.

Кренуло се од мисије конзула великих сила у Херцеговини у септембру 1875., преко Андрашијеве ноте од 30.децембра 1875.о побољшању положаја хришћана у Босни и Херцеговини на материјалном и моралном пољу, Берлинског меморандума министара спољних послова

\footnotetext{
1 N. Stojanović, Autonomija Bosne i Hercegovine, jedan neodržan govor, Zagreb 1910, 15.

2 М. Екмечић, Стварање ЈугославијеІ, Београд 1989, 85.

3 Р. Љушић, Српска, великосрпска и југословенска државна политика Србије (1804-1918), у: Велика Србија истине, заблуде и злоупотребе, Београд 2003, 305.
} 
Ђорђе Микић: Питање аутономије Б и Х као српска самоодбрана

Русије, Аустроугарске и Немачке о умирењу устаника из средине маја 1876., Рајштатског споразума Русије и Аустроугарске у лето 1876., Цариградске конференције крајем 1876. и почетком 1877., Будимпештанске конвенције Аустроугарске и Русије у јануару 1877., Санстефанских мировних преговора и закључака Берлинског конгреса 1878. године.

На почетку устанка 1875.аустроугарски министар Андраши је одбацивао све устаничке захтеве, па и аутономију, сматрајући да би то „у будућности водило уједињењу ових провинција са Србијом и Црном Гором“. У таквој ситуацији Горчаков је показао спремност да у Босни и Херцеговини уважи аустроугарске интересе. ${ }^{4}$ У односу на свог канцелара Горчакова, посланик Игњатијев „невољно се мирио са напуштањем идеје аутономије Босне и Херцеговине“. ${ }^{5}$ Британци, председник владе Дизраели и министар спољних послова Дерби, на почетку устанка су били „убеђени противници аутономије за Босну и Херцеговину“. У њој су видели претњу „по унутрашњу безбедност Велике Британије и њене империје“. Упоређујући аутономију Босне са аутономијом Ирске, Дизраели је 1.октобра 1875.говорио: „Замислите аутономију за Босну, са толико шароликим становништвом. Аутономија за Ирску била би мање апсурдна...“ И он је, као и Андраши, говорио ,аутономија се није могла дати провинцијама са толико знатним процентом муслиманског, султану лојалног становништва“. 6

Кад је Порта одбила устаничке захтеве ,једне ограничене аутономије“, које су јој доставили представници великих сила 12. децембра 1875. издала је царски ферман о испуњењу свих тражених реформи у Андрашијевој ноти од 30. децембра 1875. о побољшању положаја хришћана. Устаници су 24. марта 1876. закључили да из тих реформи мора „изаћи једна особита управа за Босну и Херцеговину, која ће обезбедити јавни ред и благостање које ће предупредити сваки извор виших заплета на Истоку“. 7

У међувремену, у јесен 1875., министар спољних послова Србије Јован Ристић пројектовао је аутономију за Босну и Херцеговину, а крајишки устаници одржавају 16. и 17. децембра у Јамници скупштину на коју су позвали и Муслимане да се заложе за формирање босанске привремене владе. То у Херцеговини ради Мићо Љубибратић. ${ }^{8}$

\footnotetext{
4 М. Ковић, Дизраели и Источно питање, Београд 2007, 149.

5 М. Ковић, Дизраели, 149-150.

6 М. Ковић, Дизраели, 141-142.

7 N. Stojanović, Bosna i Hercegovina,Ženeva 1917, 4.

8 М. Екмечић, Устанак у Босни 1875-1878, Сарајево 1960, 135. 294-295.
} 
Берлински састанак министара спољних послова Русије, Аустрије и Немачке из средине маја 1876. уводи у питање умирења устаника нове чињенице. Руски канцелар Горчаков залаже се за неку врсту аутономије у Босни и Херцеговини, предвиђајући да Русија и Аустроугарска уреде ту нову управу. ${ }^{9}$ У припремама тог састанка, немачки канцелар Бизмарк није био против тога да се хришћанима у Босни и Херцеговини у већој мери призна земља као посед, да подупре евентуалну аутономију побуњених покрајина, па и потребу аустроугарске окупације Босне и Херцеговине. ${ }^{10}$

Горчаковом предлогу оштро се у Берлину супротставио Бизмарк, који је подржао Андрашија, па је у коначни текст меморандума ушло мало од идеја руског канцелара. Ипак је „категорија увођења аутономије ушла у дипломатски речник умирења устанака у Босни и Херцеговини“. Берлински меморандум није добио сагласност Велике Британије. ${ }^{11}$

После рата Србије и Црне Горе са Турском, дошло је до састанка цара Фрање Јосипа и Александра II у Рајштату у Чешкој, уз пратњу њихових канцелара Андрашија и Горчакова, на којем је требало да се одреди став две државе према рату и устанку. Турска победа би Босни и Херцеговини ипак донела провођење реформи изнетих у Андрашијевој ноти и Берлинском меморандуму. Српски успех не би створио велику јужнословенску државу, али би се, по Горчакову, Србија проширила деловима Босне, а Црна Гора би добила Херцеговину, док би Аустроугарска могла да анектира Турску Хрватску и делове Босне уз своју границу, али ништа од Херцеговине. Андраши је забележио да Црна Гора добија само део Херцеговине, а његова земља анектира сву осталу Босну и Херцеговину. ${ }^{12}$ Тако су припреме састанка и сам састанак показали да Андраши „никада није био за аутономију Босне и Херцеговине“, те да до Берлинског конгреса никада није прелазио реформни програм од 30.децембра 1875.године, а Горчаков само крајњу могућност „широке основе административне аутономије Босне и Херцеговине“. ${ }^{13}$

Андраши је резултате разговора у Рајштату окарактерисао: „Доста за почетак“. 14

9 П. Цицмил, Босанско питање на Цариградској конферениији 1876/1877.године, Историјски зборник IV, Бања Лука 1983, 138.

10 В. Чубриловић, Босански устанак 1875-1878, Београд 1930, 160-161.

11 В. Чубриловић, нав.дело, 160-165; М. Екмечић, Устанак у Босни, 204.

12 П. Цицмил, нав.рад, 138-139.

13 В. Чубриловић, нав.дело, 224.

14 М. Екмечић, Устанак у Босни, 151-153. 
Ђорђе Микић: Питање аутономије Б и Х као српска самоодбрана

После тога долази до јачег ангажовања Велике Британије у вези са босанскохерцеговачким устанком и аутономијом Босне и Херцеговине. Министар спољних послова, лорд Дерби, на сам дан почетка српско-турског рата цинично је рекао је аустријском посланику у Лондону: „Србија и Босна уједињене биће за вас рђав сусед, а поход иде на море. Ми то не можемо спречити.“" Код разговора о аутономији Босне и Херцеговине тактика Дизраелија се сводила на застрашивање Аустрије. За Велику Британију аутономни пројекат Босне и Херцеговине уствари је био „само један од њених многобројних мина којима се желео разбити Тројецарски савез“6 ${ }^{6}$

У тој улози Британија 4. октобра 1876. силама предлаже одржавање Међународне конференције у Цариграду, која је као прелиминарна трајала од 11. до 23. децембра, а пленарна до 20. јануара 1877. године.

На првом разговору британског представника на Конференцији Солзберија и рускох Игњатијева, 6. децемра 1876., Рус је уочио да британски план за Босну и Херцеговину од десет тачака није говорио о аутономији. Ипак су на Трећем прелиминарном састанку од 13. децембра послужили Игњатијеви предлози о аутономији коју је требало увести у Босну и Бугарску као основа за преговоре. Аустријски делегати су покушавали да одложе доношење одлуке о аутономији Босне и Херцеговине, али им то није успевало. На последњем прелиминарном састанку усвојено је да се Босна и Херцеговина уједине као једна покрајина и уведе локална аутономија на основу самоуправе, широка колико то буде могуће и прилагођена потребама земље. Треба истаћи мишљење изражено у досадашњој историографији, да су прихваћени ставови на Конференцији о аутономији Босне и Херцеговине у Цариграду изашли из оквира локалне и административне аутономије, коју је помињао британски предлог из септембра 1876. године. Да су проведени предлози Конференције, Босна и Херцеговина би постала аутономна покрајина са врло слабим везама са централним властима у Цариграду. ${ }^{16}$

Турски Велики Диван, настао на Уставу, одбио је 18. јануара 1877. неке тачке или њихове делове из разлога што су се већ налазили у Уставу. После последње седнице, 20. јануара 1877., представници великих сила су до 28. тога месеца напустили Цариград.

Упоредо са радом Цариградске конференције, текли су контакти између Русије и Аустроугарске у вези са Босном и Херцеговином и Бугарском, који ће довести до потписивања Будимпештанске тајне конвенције, 15. јануара 1878., и омогућавања Русији да у априлу те године уђе у рат

\footnotetext{
15 В. Чубриловић, нав.дело, 171-172.

16 П. Цицмил, нав.рад, 146-154.
} 
са Турском. У тим руско-аустријским разговорима, цар Фрањо Јосип је, 3.октобра 1876., одбио и аутономну и окупациону Босну и Херцеговину и Бугарску. Сматрао је да је давање аутономије Босни и Херцеговини „значило овековечење анархије на земљишту смештеном у средини његових покрајина“" и да јавно мњење Монархије не би опростило министру успостављање аутономне државе међу Далмацијом, Хрватском и Славонијом. Цар се наводно бојао, да би Босна и Бугарска искористиле улазак аустријске и руске војске у њихове земље, и прогласиле самосталност, чиме би Турска изгубила могући повратак тих земаља. ${ }^{17}$

Будимпештанском конвенцијом обе стране су се сложиле да, ако не дође до распада Турске, да се за Босну и Херцеговину тражи ,аутономни режим“", а за Бугарску „широка аутономија“" ${ }^{18}$

После руско-турског рата, Аустроугарска је, заједно са Великом Британијом, једном декларацијом од седам тачака, нагласила „да се на штету балканског становништва не сме стварати ни једна велика словенска држава“", а сме ,политичка аутономија са сопственим поглавицом“. ${ }^{6}$ Андраши на почетку руско-турског рата француском посланику у Бечу каже: „Ако су Турци у стању да држе Босну и Херцеговину добро је, а ако нису, онда ћемо их ми узети: оне ће припасти Турцима или нама. “20

У руско-турском прелиминарном мировном споразуму у Санстефану, 3.марта 1878., у вези са Босном је речено: „Одмах ће се увести у Босни и Херцеговини предлози европски“, који би били модификовани из Цариградске конференције, а о којим би се старала Висока Порта, руска и аустроугарска влада. ${ }^{21}$ При одређивању аутономног уређења Босне и Херцеговине у Санстефану, Русија се придржавала девизе: „Аутономија или анархија“", што је значило намеру деобе Турске. ${ }^{22}$ Поражена Турска прихватила је да се Босни и Херцеговини да аутономија, која је захтевана на Цариградској конференцији и да њено спровођење надзиру Русија и Аустрија..

Ставови Велике Британије, Аустроугарске и Русије у вези са Босном и Херцеговином и Бугарском довешће до поништавања резултата Санстефанског мира и одржавања Конгреса у Берлину, којим је одређена аустроугарска окупација Босне и Херцеговине. У вези са Босном и Херцеговином

\footnotetext{
17 В. Чубриловић, нав.дело, 254.

18 В. Чубриловић, нав.дело, 258-259.

19 N. Stojanović, Bosna i Hercegovina,5.

20 Đ. Slijepčević, Pitanje Bosne i Hercegovine u XIX vijeku, Keln 1981, 55.

21 N. Stojanović, Bosna i Hercegovina, 5.

22 М. Екмечић, Устанак у Босни, 341.

23 В. Чубриловић, нав.дело, 383.
} 
Ђорђе Микић: Питање аутономије Б и Х као српска самоодбрана

пред Конгрес су циркулисала три нацрта решења статуса: два српска и један руски. Први српски био је за уједињење Босне и Херцеговине са Србијом, други „потпуна аутономија са законодавствима скупштине и устава, као што је устав у овој земљи“, а руски предлог је садржавао „идеју међународне војне окупације Босне и Херцеговине“. Те предлоге енглеска дипломатија је видела „као предодређене за будуће претварање описане аутономије у државу“6. ${ }^{24}$ И поред варијација између Велике Британије и Аустрије у вези са Босном и Херцеговином, у Лондону је заузет став да ће „Хабсбуршка Монархија морати да убрза своје преобраћање у државу Словена, тако што ће проширити Босну као судбоносни дар, увећавањем територије која може да уништи ту несрећну хибридну велесили“. 25

После окупације Босне и Херцеговине обустављен је у њој сваки јавни покрет за политичку аутономију, али не и ван ње.

Са Калајевим обустављањем активности на политичкој аутономији и ангажовањем на верској политици, код Срба и Муслимана се развио покрет за верско-просветну аутономију, која је почивала на црквено-школским општинама и мерифско-вакуфским установама. Србима су Турци још 1858., на захтев једне православне скупштине у Цариграду, озаконили Црквене општине као чуваре верске аутономије хришћанског народа у турској држави.Одлука је ступила на снагу после 1863 . године. ${ }^{26}$

У раздобљу аустроугарске окупације и њене политике однарођивања Срба и Муслимана, црквено-школске општине и меарифско-вакуфске установе су постале институције народног покрета. Значај су добиле и са њима повезане установе, као што су певачка друштва и читаонице. Као главне установе српског националног покретау раздобљу Калајевог режима општине су биле „своја држава у туђој држави“. ${ }^{27}$

Легалан отпор сужавању права црквено-школских општина, најпре су почели православни Срби, а затим и Муслимани.

Тадашњи председник владе Србије Стојан Новаковић, на основу положаја црквених општина у Македонији под турском влашћу, створио је теорију да независна општина у туђој држави представља „малу унутрашњу државу народа“" и да аутономни покрет за део српске буржоазије није био ништа више сем покушаја да се српски народ у Хабзбуршкој држави нађе ,за политичком трпезом као легалан чинилац исто онако како су то

\footnotetext{
24 Д. Берић, Српско питағе и политика Аустроугарске и Русије 1848-1878, Београд 2000, 459.

25 Д. Берић, Српско питање, 402-403.

26 В. Скарић, Српски православни народ и ирква у Сарајеву у 17. и 18. вијеку, Изабрана дјела II, Београд 1989, 258-259

27 М. Екмечић, Национални покрет у Босни и Херцеговини..., 616
} 
Срби и Румуни у Војводини““, док је за други део „био само основна школа политике и увод у праве борбе које су наговештаване Калајевим одласком.

Аутономни покрет Срба у раздобљу од 1896. до 1905., када је донета нагодбена „Уредба о верско-просветној самоуправи у Босни и Херцеговини“, имао је огроман историјски значај за српски народ у Босни и Херцеговини, па и за њено аутономно питање. У том раздобљу остварено је историјско преношење народних циљева са завереника на организован, легалан и савремен покрет буржоазије по градовима. ${ }^{28}$

У току покрета за црквено-школску самоуправу и меарифско-вакуфску аутономију Срби и Муслимани су се обавезали да ће ,радити и сав народ позвати“" на сарадњу да Босна и Херцеговина“" добије своју самоуправу под врховном влашћу свога султана“. Полазећи од нових форми политичког живота насталих у време аутономног покрета у складу са економским кретањима грађанског друштва Босне и Херцеговине, новоформиране грађанске политичке странке по облику, политичкој идеологији, психологији и типу су биле „народне организације“ ${ }^{29}$

У анексији и анексионој кризи 1908-1909. Српска и Муслиманска народна организација биле су за аутономију Босне и Херцеговине, а Хрватска - против. ${ }^{30}$ Организација Хрвата - Хрватска народна заједница - у првој тачки програма тврди да су Босна и Херцеговина хрватске земље. ${ }^{31}$ И после анексије главни политички циљ групе „Народ“ био је аутономија Босне и Херцеговине, као прелазна етапа ка уједињењу са Србијом и Црном Гором. Никола Стојановић је то објаснио речима: „Захтјев потпуне аутономије наша је самоодбрана, категорички императив нашег самоодржања“. 32

После анексије, српске политичке групе су, уместо позивања на султанов суверенитет и међународни мандат за мењање окупационог положаја, полагале наду у борбу за извојевање унутрашње самосталности покрајина.

На идејама Српске народне организације и њеног програма, који је израдио Одбор 39-торице крајем марта 1910., тражено је да Босна и Херцеговина постане самостална управна област, са потпуном аутономном и законодавном влашћу. ${ }^{33}$

28 М. Екмечић, Нацчионални покрет у Босни и Херцееговини ..., 616, 618, 622.

29 M. Imamović, Pravni položaj i unutrašnjo-politički razvitak Bosne i Hercegovine od 1878. do 1914, Sarajevo 2007, 159, 165-166.

30 М. Екмечић, Анексија Босне и Хериеговине и историјске последице, у: Радови из историје Босне и Хериеговине..., 378.

31 М. Imamović, нав. дело,209.

32 N. Stojanović, Autonomija Bosne i Hercegovine, 15.

33 Представка Главног одбора Српске народне организаиије са Сарајевским програмом, издање др 
Ђорђе Микић: Питање аутономије Б и Х као српска самоодбрана

Уставом из 1910. године Босна и Херцеговина није добила право на аутономију нити је постала самостална земља, већ је, и поред уставних институција, остала у зависном односу према Аустрији и Угарској. ${ }^{34}$ Са тим се није мирио Босански сабор. Његове захтеве за аутономију образложио је Земаљски савет у свом првом саборском акту. Аустроугарски државници у изостанку аутономије у Босни и Херцеговини, нису нашли лек за све народне јаде у анексији и Уставу. ${ }^{35}$

Заједничка борба Српског и Муслиманског клуба за аутономију Босне и Херцеговине разбијена је на аграрном питању, на којем је, 31. марта 1911., створена хрватско-муслиманска коалиција. Тим савезом Муслимани су аутономну Босну и Херцеговину видели у оквиру хрватских државноправних тежњи. Ту сарадњу није подржало шест посланика Муслиманског клуба, које су предводили Дервишбег Миралем и Мурат Сарић. Уз Србе сараднике владе остала су тројица хрватских посланика. ${ }^{36}$

После цепања Српског клуба 1912/1913. и стварања српске владине фракција око Данила Димовића, она је у Сабору деловала по његовом уверењу да Србе и Јужне Словене у Монархији треба ојачати ако ничим, оно бар идејом тријализма““.37

С почетком светског рата 1914. замро је политички живот у Босни и Херцеговини, а оживео у иностранству, преко Николе Стојановића и Душана Васиљевића у новоформираном Југословенском одбору. Питање аутономије Босне и Херцеговине је оживело са оживљавањем политичког живота у Монархији и формирањем Југословенског клуба са Антоном Корошцем на челу, у Бечком парламенту у мају 1917.

У лето 1918. чланови Југословенског одбора из Босне и Херцеговине - Душан Васиљевић, Никола Стојановић и Перо Слијепчевић су се сагласили, да у Одбору „увек заступају интегрално, а не делимично уједињење нашег народа, не упуштајући се на платформу присаједињења саме Босне и Херцеговине по невољи“. ${ }^{38}$ Таквим радом је Босна и Херцеговина везана за Загреб и српском народу одузет сан о вековном уједињеу тих двеју по-

\footnotetext{
Урош Круљ у име СНО, Мостар 1908., 17.

34 М. Екмечић, Национални покрет у Босни и Хериеговини..., 639.

35 N. Stojanović, Bosna i Hercegovina..., 12-13.

36 Dž. Juzbašić, Nacionalno-politički odnosi u bosanskohercegovačkom Saboru i jezičko pitanje (1910 1914), Sarajevo 1999, 85-86.

37 М. Екмечић, Нациионални покрет у Босни и Херцегговини ..., 641.

38 П. Слијепчевић, Босна и Хериеговине у свјетском рату, у: Напори Босне и Херцеговине за ослобођење и уједињење, 1919, 264.
} 
крајина са Србијом. ${ }^{39}$ Слушање Светозара Прибићевића, српске политичаре из Босне и Херцеговине, пре свих Данила Димовића и Војислава Шолу, везало је за Загреб, у жељи да се што пре реше аустроугарске власти. Они су, повлачењем брзоплетог политичког потеза, пристали да се покрајине третирају као остале јужнословенске области Хабзбуршке Монархије и удаље од директног уједињења са Србијом и Црном Гором. На тој основи су у новоосновано Народно веће Срба, Хрвата и Словенаца и његов Средишњи одбор из Босне и Херцеговине ушли Војислав Шола, Јозо Сунарић, Шћепан Грђић, Љубомир Галић, Вјекослав Јелавић, Милан Јојкић и Лука Чабрајић. С оснивањем Народног већа за Босну и Херцеговину и Главног одбора са Глигоријем Јефтановићем на челу и именовањем њене прве владе за Босну и Херцеговину са Атанасијем Шолом на челу (1. новембра 1918), до присаједињења Србији дошло је 1. децембра 1918. За такав исход политичке борбе у Босни и Херцеговини највећу заслугу имају западни и југозападни делови Босне, односно највећи део Босанске Крајине, у којој је била жива традиција босанскохерцеговачког устанка. ${ }^{40}$

Бања Лука, 17.9.2012.

39 Д. Мастиловић, Изиеђу српства и југословенства: српска елита из Босне и Хериеговине и стварање Југославије, Бања Лука 2012, 227-228.

40 Х. Капиџић, Покупај уједињењ а Босне и Хериеговине са Србијом у новембру 1918. године, у: Босна и Хериеговина у вријеме аустроугарске владавине, Сарајево 1968, 262-282. 